Tropical Medicine in London. It was finally opened in October 1899, not, be it said, without considerable opposition.

Manson is displayed to the reader in this biography as a man of tenacity of purpose, of constant questioning turn of mind, and of keen observation. His researches were characterized by constant thought about their meaning.

The book is well written in simple direct language. Perhaps it might well have ended at chapter 18, for the last chapter is a rather unnecessary addition of material about the progress of tropical medicine since Manson's time. The book is well bound and its index is clear and helpful.

\section{Medical Examination Review Book}

Vol. 9. Internal Medicine 196r Journal Review. New York: Medical Examination Publishing Co. 1962.

This collection of 1,200 multiple choice questions, grouped according to specialties, is meant for the student who wishes to discover gaps in his knowldge of general medicine. To those who have read the recently published papers in 14 different journals, on which these questions are based, and also blessed with retentive memory, the correct answers will seem obvious. Others, like the reviewer, will find the gaps in their knowledge alarmingly wide.

Students preparing for this type of examination may well find the book of practical value. It may also be used for entertainment as a quiz book on oneself, or preferably on one's colleagues.

\section{A Practice of Social Medicine}

Edited by Sidney L. Kark and Guy W. Steuart. Pp. 372, illustrated. Edinburgh and London: E. \& S. Livingstone. 1962. 40s.

With the help of the Rockefeller Foundation the Institute of Family and Community Health affiliated to the University of Natal established seven health centres, mostly in the suburbs of Durban, to serve the medical needs of an exceptionally varied group of communities. The experience of these centres in the field of public health, child welfare, nutrition and health education is told in a series of papers by members of the staff and by visiting public health workers from the United States and Israel.

The task of welding the reports of so many contributors into a coherent book must have been more than usually difficult. There can be few places in the world where several races with such differences in wealth and custom live side by side. The contrast between these groups is perhaps best seen in the closing chapters of the book, dealing in turn with the health of primitive Zulu communities in a rural and urban setting, middle class European families in Durban with problems resembling those of suburban life in England, and Indians on the outskirts of Durban whose great poverty but long traditions and stable social structure place them somewhere between these two extremes.

How much suffering due to poverty and ignorance can be prevented by even the most elementary health education is shown on every page. As a record of constructive work this book goes some way to lessen the uneasiness felt by most of us when we are reminded of the appalling conditions in which two-thirds of the world's population spend their lives.

\section{Prothrombin}

Walter H. Seegers. Pp. xxvi +728 , illustrated. Harvard: University Press. London: Oxford University Press. 1962. I20s.

The name of this book is somewhat misleading as, while a great deal of its contents are concerned with Prothrombin, the author has included data relating to the whole spectrum of plasma and platelet factors connected with the blood coagulation mechanism.

This is an unusual book in that much of it is written in the first person and can be defined as an autobiography of the research carried out by Dr. Seegers and his associates over a period of years. Dr. Seegers' opinions often differ from those of other workers in the field of blood coagulation in that he believes much of the phenomenonology that has led others to propose a large number of different plasma coagulation factors can often be explained by variations in the prothrombin molecule and its derivatives.

The text surveys a wide field: tissue factors, platelets, thrombin, fibrinogen, clot retraction, anticoagulants, vitamin $K$ and hæmostasis, as well as the chemistry of the prothrombin molecule. A historical appendix is added together with an interesting but unusual set of notes relating the author's personal reminiscences and the names of his co-workers with each chapter. The text contains a wealth of experimental detail and 8 a balanced if provocative discussion. The book is wello presented and written and a valuable bibliography is provided.

There is little doubt that this book is a valuable addition to the literature and should be of especial value to protein biochemists and hæmatologists whose primary interests lie in the field of blood coagulation.

\section{Thoracic Surgical Management}

J. R. Belcher \& M. F. Sturridge. 3rd edition. Pp. ix $+21 \mathrm{r}$, illustrated. London: Baillière, Tindall \& Cox. 1962. $30 s$.

The third edition of this handbook has been considerably improved by its complete revision and the addition of three new chapters on respiratory failure, cardiopulmonary by-pass and cardiac arrest. Valuable information is provided on tracheotomy and the use of respirators.

Until they have gained their own practical experience and concurrently absorbed that of their seniors, this manual will prove very useful and can be well recommended to those beginning a career in thoracic surgery. It will also be of value to the general surgeon and physician occasionally called upon to deal with a thoracic problem. The style of writing is simple and dogmatic, apart from some occasional lapses, and the numerous diagrams clear and helpful although occasionally for the sake of simplicity, accuracy is sacrificed as in the $\mathrm{x}$-ray section. 